\title{
Life at the edge: exploring male athlete criminality
}

Involvement in sport is not a barrier to negative behaviours, and athletes, like others in society, become involved in criminality. There is a relative paucity of research into the experiences of athletes who commit crimes. Whilst previous links exist between involvement in sport and violent and sexual crimes, a more significant body of empirical evidence is lacking. This paper utilises the concept of elite interviewing to explore the stories of ten male athletes who committed criminal offences either during or immediately after their athletic careers. Key emerging themes include the restrictive nature of sport, the need for excitement, risk appetite, and the impact of social influence. Male athlete behaviour is considered within the model of edgework, and themes are analysed as potential paths to edgework activities. The findings suggest the nature of both sport and male athletes can result in them seeking edgework experiences, and committing crimes as a consequence.

Keywords: crime; edgework; elite athlete, elite interviewing; athlete criminality

\section{Introduction}

Sport is a microcosm of society, and a laboratory for general human behaviour (Parlebas 2002) and increasingly, the visibility of athletes has intensified (Driessens 2013), leading to their everyday lives and activities facing far greater scrutiny and investigation. Members of society are actively encouraged to partake in sport, with participation widely hailed as a positive and beneficial experience, whose benefits include enhanced confidence and self-esteem; increased social integration, collective 
identity and increased cohesion; improved health; and enhanced employment prospects (Giulianotti 2015).

While participation in sport has positive outcomes, some have cast doubt over the assumption that participation in sport is consistently positive. Critcher (2000) recognises that those leading and playing sport may not always promote the pro-social values they are proclaimed to bestow. Utting (1996) reinforces this by explaining that not all sports are characterised by fair play or, most relevantly to this study, the absence of any criminal associations. Although people participate in sport according to their own volition, Caruso (2011) questions the voluntary nature of some sports participation, and argues that in some cases it can involve coercion, threat, aggressive behaviour, and extreme competition. Whilst sport is praised for enabling the development of values and interpersonal skills such as self-control, some have questioned how viable sport is as a mechanism to deliver such values.

\section{Research into sport and crime}

Sport has traditionally been associated with crime as a means to divert individuals from criminal activity (Nichols 2007). While evidence exists of sporting programmes and crime prevention outcomes, it is important to avoid making the simple assumption that sport 'works' (Groombridge 2016). Indeed, Hartmann and Massoglia (2007) suggest that involvement in sport may expedite and promote antisocial behaviour, whilst potentially acting as a risk factor for aggressive and illegal behaviour.

Awareness of the association between sport and acts of crime has increased over recent years, largely due to high profile cases of historic sex abuse by those in positions 
of responsibility over athletes (including the cases of Larry Nasser in the US and Barry Bennell in the UK). These high-profile cases have shown that the arena of sport is not immune from controversy and crime, and is perhaps an optimal space for violence and abuse to occur (Fisher and Anders 2019). The nefarious acts of athletes also draw attention, as questions are asked about the prevalence of athlete criminality. The potential link between sport and crime is highlighted by Crabbe (2000) who acknowledges the need to recognise that the exhilarating experiences people seek within sport can be replicated by taking drugs or committing crimes.

Jackson, Gilliland and Veneziano (2006) describe crime as a natural function of society, and as such criminal incidents will occur in all walks of life, including sport. Athletes, like others in society, commit crimes. Teitelbaum (2005) identified that sports heroes have been known to act in ways that have considerably damaging consequences. There is an existing body of knowledge into the criminal activities of athletes focused on the North American collegiate system, which considers the potential predisposition of athletes towards criminal or anti-social behaviour (Yar 2014), with some authors claiming that being an athlete makes it more likely for an individual to commit a crime (Kudlac 2010).

Research conducted to date has a focus primarily on the activities of male athletes, with very limited reference to the behaviour of female athletes. The majority of research focuses on the following three main types of crime perpetrated by male athletes: violent crime, violence against women, and sexual violence/sexual aggression. Kudlac (2010) notes that historically and cross culturally there is no more consistent a relationship than that between males and crime. It is therefore unsurprising that links have been 
consistently made between masculinity and violence. For some, the masculine socialisation process inherent in sport is held primarily responsible for displays of violence on and off the field of play (Terry and Jackson 1985). Sport enables athletes to embody traditional masculine qualities such as power and strength and exhibit violence legitimately. The ideals of sport and masculinity create an environment where in many cases violence is not only accepted but encouraged (Messner 1990; Messner and Sabo 1990). A direct link has also been made between participation in sport and violent behaviour away from the sporting arena (Forbes et al. 2006). Research suggests that participation in sport is linked with higher levels of violence and ultimately assaults. However, others argue that this apparent link is weak (Young 2000), with more historic findings suggesting there is no link at all (Caron, Halteman and Stacy 1997).

Continued media interest has led to what Forbes et al. (2006) refer to as a 'common belief' that male athletes are more likely than men in other areas of society to behave violently towards women. Given the shift in public awareness of, and concerns about, domestic violence, and the increased reach of the media afforded by the internet (Hunton 2012), cases of domestic violence involving sport stars now receive significant media attention. The vast majority of cases refer to men. However, the arrest of US soccer player Hope Solo, and the allegations made against her in 2014 (charges were dropped in 2018), highlighted that domestic violence is not purely the preserve of men. Domestic violence cases have inevitably led to public and professional concern about the potential link between sport and violence towards women. It has been suggested that one consequence of involvement in the aggressive, hyper-masculine and violent world of sport may be an increased level of violence towards women (Coakley 2001). 
However, as with general links to violence, there are concerns regarding the strength of this association (Messner and Stevens 2002).

According to Sawyer, Thompson and Chicorelli (2002) male athletes are deemed to be a 'high-risk' population when committing sexually violent acts. Significant relationships between athletic participation and sexual aggression have been identified, particularly in US college athletes (Woods 2007). However, as Caron, Halteman and Stacy (1997) explain, the fact that a number of athletes are accused of rape does not mean they are committing a disproportionate amount of rapes in comparison to the rest of society. Leonard (2006) casts doubt on studies that claim a disproportionate number of male athletes are involved in sexual offences, explaining that findings are often based on arrest statistics rather than focusing on who is actually charged with, and guilty, of an offence.

Some have attempted to offer theoretical explanations for athletes committing crimes. These tend to centre on athletes as a 'special population' of people who are socialised into believing their behaviours and transgressions will be accepted by those in positions of authority (Atkinson and Young 2008). For some athletes, their egos may lead them to defy and challenge law enforcement (Jamieson and Orr 2009), encouraged by their sense of superiority and privilege. The tendency of elite athletes to demonstrate narcissistic personalities (Teitelbaum 2005) may be a contributing factor to athlete criminality. This sense of hubris can lead to the athlete overestimating their standing in society and believing that they are beyond reproach (Coakley and Donnelly 2005). Additionally it has been suggested that the violent behaviour of athletes away from the 
field of play may be due to a sports culture that endorses aggression and violence (Yar 2014).

In general however, explanations for athletes' criminal behaviour often lack depth and are based on assumptions about personality traits of athletes that are generalised to the whole athletic body. Atkinson and Young (2008) explain that often athletes who commit crimes are identified as isolated offenders whose behaviours are not typical of their sporting culture, and therefore unrepresentative of usual athlete behaviour. Overall, there is a need for further exploration into athletes and crime. The majority of National Governing Bodies and players' associations have already acknowledged the need to support athletes both during and after their careers, and call for a deeper understanding of the demands placed on athletes. As Jamieson and Orr (2009) argue, a deeper exploration of athletes who are involved in crime will enable solutions and programmes to be developed to help athletes. More can be learned about deviance and crime in sport by exploring its parameters rather than trying to pretend that crime doesn't exist (Atkinson and Young 2008).

There has been a stagnation of research into athletes and crime over the last 1520 years (McCray 2015), with momentum clearly slowing. Findings are also predominantly based on quantitative data, and the question is rarely posed to athletes, 'why did you commit a criminal offence?' Specific details of offences committed by athletes are also rarely addressed in the literature. As such, this paper makes a contribution to knowledge through a rich qualitative exploration of athlete criminality. 


\section{Edgework}

As a guiding theoretical perspective, this paper will utilise the concept of edgework to develop a better understanding of athlete criminality. Edgework was originally proposed as an account of voluntary risk-taking (Lyng 1990), and has subsequently been described as a risk paradigm (Anderson and Brown 2010). Edgework describes how individuals negotiate boundaries of order and chaos (McGovern and McGovern 2011) in activities where there exists a 'clearly observable threat to one's physical and mental wellbeing or one's sense of ordered existence' (Lyng 1990, 857). Thrilling and intense activities place the individual on the edge of their physical and/or mental abilities (Anderson and Brown 2010). Far from being a way to describe all risk, edgework is distinct and occurs for the thrill of the action (Newmahr 2011).

Edgework is characterised by risk and control, specifically the ability of an individual to effectively maintain control in a situation that most people would consider uncontrollable (McGovern and McGovern 2011). Katz (1988) describes the extreme feelings associated with edgework experiences, as people move in and out of rational control. They may feel exhilaration, omnipotence and an exaggerated sense of self (Lyng 1990). Halsey (2008) observes that for some, the hyper-reality of the edgework experience may be beyond explanation. Lois (2003) argues that edgework can be an addictive and exhilarating experience, with Lyng (2004) claiming that it can be selfactualising.

\section{Edgework and Criminal Activity}

The concept of edgework is grounded within the context of high-risk sports. As such, its applicability to the risk behaviour of athletes is clear. Various extreme sports have been investigated, including base-jumping (Forsey 2012) and white-water kayaking (Fletcher 
2008). In addition to sport, edgework theory is applied to a vast spectrum of contexts including: aid work (Roth 2015); S\&M (Newmahr 2011); finance (Smith 2005); and women in violent relationships (Rajah 2007). There are concerns that its application is too broad, and that edgework is in danger of losing its expounding ability (Bunn 2017). Critics have also focussed on the disproportionality of the theory in its focus on men (Newmahr 2011), and questioned the applicability of the theory across gender, race and class (Laurendeau 2008).

One relatively recent application of edgework theory is as an explanation for criminal and deviant activity (Anderson and Brown 2010; McGovern and McGovern 2011). Lyng (1993) acknowledges the potential of the edgework model to explain why individuals commit crime. In effect, crime is essentially a form of high risk edgework. Crime shares many features of edgework behaviour, namely the chaotic and uncertain circumstances that many offenders navigate. It has long been acknowledged that the commission of a criminal act requires an individual to transcend defined boundaries.

The application of edgework to criminal activity acknowledges the notion that the criminal experience can be exciting and pleasurable (Bengtsson 2013), and supports those who believe that committing crimes conveys both motivation and meaning (Sandberg 2009). Crime, like edgework, can offer a form of escape, and act as a form of cultural resistance and source of exhilaration (Anderson and Brown 2010). Edgework may also offer a potential explanation for the escalation of criminal acts over time, as 'edgeworkers' continually modify the edge (Bunn 2017), seeking ever higher level risks. Using edgework as an explanation for male athlete criminality is particularly appropriate in this study, given its historic use in both sport and crime. 


\section{Method}

This study adopted a qualitative approach to explore the experiences, behaviours and feelings (Holloway and Wheeler 2010) of elite male athletes who have committed criminal offences. Despite not being the dominant methodology within criminology, qualitative methods serve a crucial role in the understanding of crime (Hochstetler and Copes 2016). Helfgott (2008) states that the dominance of quantitative criminology means that the motivations, meanings and experiences of criminal behaviour, and the factors that shape an offender's decision-making processes are not well understood. Qualitative methods enable the complete story of crime to be told. This study makes a contribution to knowledge through a qualitative investigation of male athlete criminality, and in doing so it redresses the current methodological imbalance in sport research.

This research utilised in-depth interviews to explore participants' stories. Stories enable us to make sense of our lives and make clear connections between experiences, actions and aspirations (Presser and Sandberg 2015); we know the world through the stories we tell (Presser 2009). People lead storied lives (Smith 2010), and narrative inquiry provides a way for these stories to be captured and analysed academically (Munro Hendry 2007). Narratives not only enable people to understand their present life (Alea and Bluck 2003), but also to 'rewind time' and re-evaluate historical actions (O’Connor 2015; Miller 2000). There is a significant body of support for the use of narrative inquiry in exploratory research (Polkinghorne 2007). Advocates of narrative inquiry highlight the quality of the data it can produce; rather than skimming the surface, narratives offer rich, embodied insights into people's lived 
experiences and can illuminate a person's life course over time (Carless and Douglas 2017).

Narrative inquiry allows for unique and enlightening stories to be heard (Jones 2003) and is especially effective when exploring complex and subjective experiences (Woike 2008). This form of inquiry is especially useful when examining intentions and patterns of reasoning; areas particularly important when considering the thought processes involved in committing criminal acts. Narrative inquiry is highly appropriate for research into both athletes and criminals. Smith and Sparkes (2009) emphasise that narrative inquiry is a tool to assist in the process of representing and interpreting the experiences of sports people. It provides a unique way of looking at significant aspects of a person's life, particularly those that are traumatic such as crime (Chase 2005). This study explores the narratives and stories of 'elite' male sports participants.

The term 'elite' is traditionally used to refer to those whose abilities and qualities mark them out as superior within a group. Elite people are considered to be powerful, talented and superior in quality or skill, and elite athletes are no different. There are numerous differences in definitions of what constitutes an elite athlete (Moston, Engelberg and Skinner 2015). The term elite has been used to describe athletes who have played sport for a certain amount of time (Gladwell 2009), attended top level competitions such as the Olympics (Grant and Schempp 2013), inter-varsity athletes (Steiner, Denny and Stemmle 2010), members of national squads (Bertollo et al. 2012) and professional athletes (Swann, Moran and Piggott 2015). Chi (2006) discusses the benefits of studying elite athletes and advocates the use of small samples 
of exceptional athletes, and examination of their absolute expertise, to gain insight into the athletic world they inhabit.

A small but emerging area of social science research explores the intricacies associated with interviewing elite participants (Lancaster 2017). An important area of qualitative research, elite interviewing as a method aims to fill the gap in our understanding of a group of people considered by many to be superior as a result of their power, talent or privileges. In many instances, very little is known about the world in which elites exist. By studying them researchers are provided with a unique opportunity to understand the worldview of influential people, who often have access to exclusive information that is not readily available to the public (Mikecz 2012).

For the purpose of this study, a relatively small, but powerful group of 'in the know' male athletes (Mikecz 2012), were interviewed, where the focus of the interviews was on the unique insight they possessed (of both crime and being an elite athlete). In accordance with the definition utilised in this research, the interviews were of importance given the positon and influence of the participants, the extensive knowledge that these elites possess (Swann, Moran and Piggott 2015), and the privileges that they are, or were, afforded (Rice 2010). The elite interviews provided a unique dataset for analysis, offering a rare opportunity to understand the experiences and worldviews of those who have had significant influence, and power, in their athletic fields.

Access to elites can be particularly challenging due to the many barriers between the researcher and elite participant. This is one of the reasons for the lack of research 
into elites, who can protect themselves from intrusion. The establishment and existence of barriers is what sets elites apart from the rest of society (Shenton and Hayter 2004), and contributes to defining them as elite. These barriers can act as shields, protecting elites from the scrutiny of the public, and from the intrusive nature of research (Duke 2002). A number of recommendations are offered to researchers to increase their chances of gaining access to elites (Morris 2009). The key recommendation, which was utilised within this research, involves obtaining an influential 'sponsor' to endorse the research (Welch et al. 2002) that participants would recognise.

In order to access a niche sample, non-probability purposive sampling technique was used. This involves sampling on the basis of identifying people who are relevant to the research questions (Bryman 2004), and who will provide information that could not be obtained via other sources. Gatekeepers were contacted by the researchers, and athletes who met the inclusion criteria were initially approached by the gatekeeper who passed on the researcher's details if they were content to be part of the project. After initial contact was made, snowball sampling was used to establish links with other relevant participants. Penrod et al. (2003) support the use of snowball sampling in research where participants are not easily accessible or where anonymity is important.

The finalised inclusion criteria were identified following approval from the University ethics panel. The criteria specified firstly that athletes should be over the age of 18; secondly, they should be either participating or should have participated at an elite level (national, international or professional) within their sport; and thirdly, they should have committed a criminal offence for which the punishment involved, or exceeded, a police caution, either during or directly after their athletic careers. The 
inclusion criteria did not contain any stipulation regarding gender: both female and male athletes were approached by gatekeepers, and followed up by researchers. A number of female athletes initially made contact with the researchers, however, they subsequently withdrew their consent. The researchers continually attempted, unsuccessfully, to access elite female athletes throughout the project.

Table 1 provides an overview of participants, and further details on the crimes they committed. Each participant was provided with a pseudonym to ensure anonymity, and given the choice to include specific details of their sport in the study.

\section{Insert Table 1 Near Here: Overview of Sample}

Thematic analysis was used to explore the data whereby themes and patterns emerging from the data were identified and categorised (Holloway 2008). Data for this study were generated from a wider project focussed on exploring the experiences of male athletes who have committed crimes.

\section{Results and Discussion}

The focus of the findings that follow enable an edgework perspective to be applied to the phenomenon of male athlete criminality.

\section{The restrictive nature of sport}

Given the media hype that surrounds elite athletes, particularly those who make a living through sport, it would be easy to assume that playing professional sport is a dream come true (Green 2009). Surprisingly, some of the participants refer to their experiences of elite sport in less positive terms. Both Archie and Charlie described 'going to work' 
in mundane terms when they discussed their football careers. Harry spoke of the confusion he experienced playing sport professionally and noted that, though other people considered this impressive, he didn't actually enjoy it, stating, 'the game I had played for fun had taken over and become a bit more you will do this, and you will do that, and I just didn't enjoy it'.

The attitude of some of the participants echoed the study by Carter and Carter (2007) which found that nearly half of their participants were unhappy with some aspect of their life as NFL players. Despite the links made between sport and happiness in the literature (Kiyani, Mohammadi and Sattarzadeh 2011), it is clear that the happiness of elite athletes cannot be presumed. The tendency of the public to idealise elite athletes has led to many misconceptions (Reardon and Factor 2010).

For several participants in this study, their decisions to commit crime were invariably linked to feelings of discontentment in some area of life, and deep-seated personal issues. To the outside world, these male athletes were living charmed lives, but the reality was different. In elite sport there is intense competition for places and success is limited. Elite athletes are often considered expendable and easily replaced by another athlete who is ready to take their place; they are treated as widgets, or marketable assets, within a modern, corporate and media-driven arena (Connor 2009). Participants referred to the pressure they felt to be successful, and how this impacted upon their happiness and enjoyment of their sport. George explained how the pressure to be successful meant he wasn't being natural stating, 'I felt like I wasn't myself on the pitch, I was trying to remember instructions, trying to listen to different people on the side-lines, and it always felt like you were playing for your future'. 
In addition to feeling under pressure to perform, participants discussed their perceptions of a loss of freedom and overly restrictive and constraining environments. For some, sport offers an opportunity for release from societal oppression, acting as a safety valve and providing temporary liberation (Langseth 2011). However, for George, the constraints of his sport, coupled with the pressure he felt to perform, meant he felt very little freedom at all:

training became something that didn't feel enjoyable anymore, and felt like...that I was having the joy coached out of me, and that love and freedom that I felt on the pitch coached out of me...it all become too much like a $\mathrm{f}^{* * * * *}$ job...I felt restricted. This game that brought me so much freedom, all of a sudden becoming very structured and rigid to the point I didn't enjoy it anymore.

Gruneau (1980) acknowledges the lack of 'play' that exists in modern, repressive, sport, explaining that over-regulation has resulted in leaving a lack of freedom and creative expression. George felt like he had 'shackles' on when playing elite sport.

Whether feelings of constraint are caused by sport (Murphy and Waddington 2007) or are self-imposed (Roderick, Waddington and Parker 2000), it is likely that when combined with feelings of a loss of freedom and over-regulation, athletes may feel they no longer have power or control over their lives (Connor 2009). This may have led the athletes within this study to pursue experiences that enabled them to regain some control. Edgework experiences allow individuals to feel a sense of control in their ordinary, largely constrained, lives (McGovern and McGovern 2011), and athletes may pursue edgework activities as they attempt to challenge and escape from constraining 
structures (Lyng 2005). Seeking edgework experiences may be a compensatory response to the limited influence people have over their routine existence (Anderson and Brown 2010).

For athletes, a perceived lack of control over their lives may result in them feeling a degree of anomie, and a sense of meaningless and detachment (Carter and Carter 2007). In his study of delinquency, Miller (2005) highlighted that alienation in combination with institutional constraints, conspires to create the conditions that enable forms of edgework to occur; edgework can provide alienated and overly controlled individuals with a thrilling and exciting escape.

\section{The need for excitement}

A number of participants spoke about the sensation involved in committing crime. Feelings of enjoyment were mentioned by several participants. Harry commented, 'If something went on, I just seemed to be in the middle of it...I quite enjoyed it in a bizarre way', whilst George noted 'some of those feelings, like feelings of elation and at times camaraderie as well, that I experienced on a football pitch, in a changing room......I got that from crime as well'.

Zuckerman (1979) suggested that individuals need to experience novel and varied sensations and that in seeking sensations, they are prepared to take social and physical risks, which may inadvertently, or deliberately, result in criminal action. Katz (1988) refers to the seduction and 'sneaky thrill' of crime that may enable a person to escape a mundane existence. This was reinforced by Miller (2005) who emphasises that in addition to its seductive nature, crime is a powerful and emotional experience. 
From a cultural perspective, one reason for committing crime is the search for excitement (Ferrell 1999). Blackshaw and Crabbe (2004) argue that deviant behaviour in sport is evident because it makes the heart beat faster. Finn explained that although money was his primary motive for smuggling drugs, he also experienced an element of excitement, and that 'anyone who tells you otherwise is lying, it's a buzz'. For some escaping law enforcement can be addictive (Kellett and Gross 2006), and the fear of being caught plays a key role in the thrill of crime. Dougie explained how he derived satisfaction from evading the police after committing a crime stating, 'I used to get a buzz getting away with it'. Katz $(1988,9)$ stated that 'getting away with it' is a way of exhibiting personal competence, which is particularly relevant to this study as a number of participants committed crimes with friends.

This study suggests that some crimes are not committed solely for rational purposes as cognitive theories would suggest, and that reasons may be more emotional and fit cultural theories suggesting that crime can be thrilling and seductive (Katz 1988). Although elite athletes are often considered more conscientious than athletes competing at lower levels (Allen, Greenlees, and Jones, 2011), there is evidence to suggest that athletes can, and do, exhibit impulsivity (Maher, Thomson and Carlson 2015), and sensation-seeking behaviours (Zuckerman 1983). In certain circumstances, an athlete may view intense and thrilling edgework activities, and ultimately crime, as an alternative avenue to fulfil their need for excitement.

\section{Risk appetite}

The notion of risk-taking emerged from analysis of the interviews. Joshua explained that as an athlete he was more inclined to take risks: 
A lot of people I have come across who haven't played sport tend not to be as risky. Where perhaps being part of sport is where you can say 'yeah that's scary but I'm still going to do it' - where you manage it (the risk), or you lessen it. Yeah, you're scared but still kind of do things when you are scared, where perhaps other people say 'yeah I'm scared so I'm not going to do it...and I always thought maybe that's why I became a sportsman.

Athletes are not strangers to risk-taking. It could be argued that all sports present a danger, or risk, to an athlete whereby sport provides an avenue for fixation and obsession that may be detrimental to their capacity for human affiliation or their objectivity towards effective decision-making on and off the field of play (Russell 2005). In addition to the risks that athletes take during competition, there is also evidence suggesting that athletes are expected to take risks with their own health in order to play (Murphy and Waddington 2007).

Zuckerman (2007) suggests that risk-taking in athletes and sensation-seeking are inextricably linked. Risk-taking could be seen as a desired quality in athletes. Langseth (2011) suggests that the values associated with taking risks, such as individualism, creativity and spontaneity, encourage athletes to seek out sports. Corkery (2011) describes the respect that can be achieved by a person defying danger. Taking risks can also be an opportunity to demonstrate courage and serve as a strategy to attain social status (Ermer, Cosmides and Tooby 2008), enabling a person to enhance their reputation in the eyes of their peers. Taking risks is also associated with peer influence, particularly within individuals with high sensation-seeking tendencies (Horvath and Zuckerman 1993), and it may be more 'socially desirable' for male athletes, in particular, to be less risk-averse in order to conform to masculine stereotypes (Coakley 
2001). Some athletes may take risks to achieve peer recognition, or establish alliances with their peers (Sulloway and Zweigenhaft 2010).

Crieghton et al. (2015) suggest there is a danger that those engaged in extreme, high-risk activities may consider themselves exempt from expectations that govern the lives of most members of society, and the constant pushing of boundaries may cause boundaries to be challenged in other areas of life. While not seemingly involved in 'high risk' sports, both Charlie and Joshua touched upon notions of feeling 'protected' or that the rules that applied to others did not apply to them. Charlie observed, 'as a footballer you think you are infallible, I use the word untouchable'. Meanwhile, Joshua commented, 'so it isn't that you aren't aware of the consequences of things, but of course the consequences don't apply to you, because if they did you wouldn't do it'. Frey (1991) noted that athletes often express feelings of invincibility and possess a false sense of control, which may lead to underestimating the risks they take. This was particularly evident in the cases of Finn, George and Archie, whose behaviours escalated over time as a result of not being caught by police.

A person's attitude towards risk will play a role in their decision-making on a daily basis. It has been suggested that lowered perceptions of risk can serve to predict high-risk lifestyles (Krause et al. 2014), such as involvement in crime. Joshua stated that he knew the risks involved with drug smuggling, but dismissed them, and chose to accept those risks, thus demonstrating a high 'risk appetite' or a high level of 'risk acceptability' (Aven 2013): 'Of course there are consequences, of course there are people that go to jail, I know them, but I'm not going to get caught so I don't have to think about that'. 
Within the theory of edgework, risks are believed to be pursued for the captivating appeal of risk-taking itself (Bunn 2017). The male athletes within this study showed an awareness of, and acceptance of, risk. Although they did not speak of their desire to take risks, it was clear that as athletes they felt their perception of risk, and its consequences, differed from non-athletes'. Their increased risk appetite may have increased their likelihood to pursue edgework activities, with their crimes occurring as a form of this 'risky behaviour' (Dhami and Mandel 2012).

\section{Impact of social influences}

When discussing their stories and exploring their reasons for committing crimes, several participants discussed the role of friendship. Friendships are recognised as being essential for health and well-being (Way 2013). One striking finding was the influence that 'old' friends from outside of their sports had on the male athletes, even when they recognised that their friends' criminal activities were having a negative effect on the future of their athletic careers. Isaac described how important his local friends were to him and why they spent time together: 'It isn't because you do the same thing, it's because you have the same life...I didn't hang out with them because they were drug dealers, I actually liked them, they were my friends'.

While primarily used to consider delinquency, there is a large body of literature that considers the role of peers on offending behaviour; one of the most stable predictors of delinquent behaviour is having delinquent friends (Haynie, Doogan and Soller 2014). For elite athletes, there is a danger that not only could their associations with deviant or criminal friends result in them committing crimes, but that these relationships could adversely affect the development of their talents (Patrick et al. 
1999). Joshua explained that in the end he turned to the friends who he had always known were criminally connected and became embroiled in crime overnight.

Both Billy and Dougie highlighted that despite spending time training and competing, they would still seek out and spend free time with old friends, and at weekends would be fully immersed in their activities. Billy's friends provided an escape from boxing when things were going badly, and gave him a chance to be 'normal' again. Participants expressed a reluctance to disassociate from their 'old' friends, regardless of their impact. Isaac's friends offered him something that authority figures couldn't appreciate. When told they were bad for him by coaches or teachers, he stated:

No, they're not, they are ambitious, for me they were ambitious, they weren't just happy to sit at school, get a good education so they could get a job that pays them $£ 20$-30k a year, they wanted it all...even though they were doing it the wrong way, in a negative way. I understand that now, at that time I was attracted to people and wanted to be around people that wanted to push themselves.

The acceptance of their peers was a key feature for several participants who continued to invest in their friendships. Friends can act as a source of safety and comfort (Carr 2012), which was particularly important for Isaac as he opened up and told his old friends about the sexual abuse he had suffered as a child. Being fully accepted by his peers increased his commitment to, and investment in, his friendships. Isaac's friends provided emotional support, and their approval positively influenced his feelings of self-worth. He observed: 
The friends that almost ruined my life, they're still there now, they were really supportive, they helped me...I live a completely different life to them now, but we are still mates, and that's the most important thing I have learnt is that you can learn so much from everybody. Just because someone sells drugs doesn't mean they 're a bad person... its about understanding people.

Social support networks can act as a 'buffer' (Vaux 1988) and enable people to deal with stressful situations and experiences. While a number of participants still see their friends, despite their lives now being vastly different, over time the intensity of friendships with those outside sport reduced. Isaac's movement away from old friends was largely due to time available since fully committing to his sport, resulting in less time to invest in these social relationships (Patrick et al. 1999). In their study of adolescent academy level footballers, Adams and Carr (2019) found athletes expressed feelings of disconnection from friends when making the choice between two identities their old friends or their potential new career.

Kinship has been described as one of the most powerful forms of friendship, and de Vries (2018) indicates that while friendship is important, it is kinship that occupies the 'top billing' in our lives. Participants explained that their loyalty and protection towards friends was due to them being 'family'. Ethan observed, 'You stick up for your friend - "like you would on a pitch, like you would on a street, they become part of your family'. On this theme, Isaac commented:

My family's great but I didn't really have one, it was fractured, everyone was having their own problems and going a bit mental, and then with the friends I had, and we used to sell drugs and that, it was a little family, a little gang and it was cool. 
Friends and team mates thus occupy the role of 'fictive kin' (Maupin 2017), and are afforded protective behaviours that would ordinarily be reserved for the biological family.

Although loyalty is a trait frequently associated with friendships in children (Weiss, Smith and Theeboom 1996), it was clear that the participants valued loyalty highly. Both Dougie and Ethan made personal sacrifices for their friends that directly impacted them, in terms of gaining criminal records. Dougie volunteered to return to a crime scene to retrieve something for a friend, which resulted in him being arrested. Ethan refused to give the names of the people involved in a fight (three of his team mates), resulting in a conviction based on injuries the victim suffered, rather than those he had inflicted. He explained that he didn't want to lose friends: 'you stick together like you would on a rugby pitch'. Harry also highlighted the notion of sacrifice but spoke more about protectiveness and loyalty particularly towards team mates, noting:

I'm very moralistic, I'm very caring, and think its born by learning things through rugby and sport and making sure your mates are ok, and looking after each other... The sport I play is all about looking after each other, absolutely it's all about looking after each other and I think I probably took that to another level.

For Harry, the need to help and protect often meant getting into unnecessary trouble and often, as in Ethan's case, when the fight wasn't his own: 'I was always the helper outer... always go and help someone but always end up being at the front of it'. Pappas et al. (2004) discussed the strong bonds of allegiance and loyalty that form through sport, as is apparent in both Ethan and Harry's case. 
Dougie, Isaac and George discussed their friendships around the time they initially committed crimes, aged 18-19. Arguably they may have been drawn to their friends because of their life stage. Adolescence has been described as a period of storm and stress where the social focus shifts from family to peers (Pummell, Harwood and Lavallee 2008). Research consistently shows that during adolescence the influence of an individual's friends takes primacy, and association between delinquent behaviour and the behaviour of friends is stronger than other risk factors (Haynie, Doogan and Soller 2014).

The concept of edgework has been utilised to explore juvenile delinquency, with Miller (2005) advocating its power to explain the intricacies of offending behaviour in adolescents. Adolescents occupy a marginal place in society; they are not yet adults but are not children, and as a consequence adults, or authority, control nearly all aspects of their behaviour. The opportunities for adolescents to pursue truly free, autonomous and self-directed behaviours may only be possible through deviant activities. Adolescents may be particularly susceptible to the seductive nature of edgework experiences, as they often carry a strong sense of immortality (Lyng 1990). Adolescents are also susceptible to anomie, as they may feel isolated and detached from the society to which they belong (Miller 2005).

Parallels between the distinctive nature of elite athletes and adolescents have been drawn. In the same way that adolescents are constrained, controlled and ordered by others, athletes too are susceptible to feeling a lack of power and autonomy in their lives (Connor 2009). Teitelbaum (2005) claims that some athletes are so indulged that they maintain a state of 'terminal adolescence', never growing up because they don't have to. 
Athletes may develop unrealistic views of themselves, and Teitelbaum identifies features such as self-centeredness, insensitivity to the needs of others, and a sense of invincibility. House (1989) describes ‘the jock's itch', whereby athletes do not mature into adults, and behave at 30 in the same way that they did at 13. Ortiz (2004) terms the effect 'spoiled athlete syndrome'. This stunting in emotional growth may be due to limited access to life experiences outside the athletic world. Consequently, athletes may be highly susceptible to temptation, just as adolescents can be. Furthermore, through being sheltered in their sporting world, athletes may find it hard to identify social boundaries (Kudlac 2010).

The male athletes within this study demonstrated immaturity at times, particularly when discussing their friendships, and the roles that friends played in their commission of crime. While some participants discussed friendships when they were younger, a number discussed the importance of their friendships as adults. It is believed that by the age of 18 , resistance to peer influence is fully developed and does not increase beyond this age (Steinberg and Monahan 2007). Therefore, it was surprising to hear adult men speak about committing crimes to protect friends at an age where they might be expected to be sufficiently emotionally developed to resist the influence of peers. The way participants talked about their friends was reminiscent of the ways in which an adolescent would view their friends.

\section{A Framework for Understanding Male Athlete Criminality}

Based on the four emergent themes in this study, the framework proposed in Figure 1 offers a graphic illustration of the relationship between elite athletes, edgework and crime. It considers the links between the restrictive nature of sport, the need for excitement, risk appetite and the impact of social influence and an elite male athlete's 
edgework behaviour. The framework encapsulates elements of Miller's (2005)

Edgework Model of Delinquency, demonstrating that much like juveniles, athletes may seek edgework activities in response to their position in society. As constrained and restricted individuals, who may have no reason to emotionally mature, athletes may feel alienated and approach edgework in the same way an adolescent, or juvenile, would.

\section{Insert Figure 1 Here : A Framework for Understanding Male Athlete Criminality}

The framework presents potential paths to edgework for male elite athletes, and acknowledges that crime may be committed as a form of edgework. The findings presented clearly illustrate a variety of contributory factors to athletes committing crimes. The need for excitement and propensity for risk expressed by athletes could lead them to exploring edgework activities. The findings also showed that some of the athletes were significantly influenced by friends and team mates in negative ways. Whilst friendships can be sustaining, for some athletes, their social influences may place them in situations where edgework activities are pursued more freely.

\section{Conclusions}

The current study contributes to the body of academic work into crime and sport by focusing on the narratives of male athletes who have committed crimes. The study provides an original insight into male athlete criminality. There were extensive efforts to obtain a sample that was reflective of all athletes. It is clear that female elite athletes do commit crime, however accessing their stories was extremely difficult. Future research should attempt to tackle this access issue, and explore the criminal experiences of female elite athletes. Criminal acts by all athletes should be considered fully, and there is a need to better understand the background of the athlete and circumstances 
surrounding their criminal offences if we are to better understand athlete criminal experiences and prevent future athletes from making similar mistakes.

There are commonalities between the worlds of sport and crime. Hartmann and Massoglia (2007) urge policy-makers to avoid complacency when encouraging and facilitating sport, given that multiple indicators of sport participation are linked with various forms of antisocial and potentially criminal behaviour. It is apparent that sport produces both prosocial and antisocial behaviours. For some athletes, involvement in sport tends to minimise deviant behaviours whereas for others the tendency is heightened (Hartmann and Massoglia 2007). Dunning and Waddington (2003) argue that sport promotes positive normative effects as well as less attractive, more socially dysfunctional outcomes, such as crime. It is important that sport is viewed as one of the many influences that could lead to the pathway of crime, rather than an absolute.

The use of edgework as a potential explanation for athlete criminality is based on subjective interpretation. There is no singular reason for an athlete or individual committing crime, although an increased awareness of the types of conditions that were apparent for these particular athletes may help in understanding the lived experiences of male elite athletes. Within the sample of athletes interviewed in this study, there were clear links between their need for excitement and their risk-taking behaviour. Some felt constrained by their position as athletes and acted in ways that provided them with opportunities to regain control. To a concerned coach, a friendship group may appear negative, but to the athlete they may actually provide essential support. It is apparent that if crime is to be prevented in athletes, or if athletes are to be supported on a return to competition following prosecution, individual circumstances need to be carefully 
considered. This study provides unique insights into the experiences of ten male athletes. It has led to the development of a framework that can be tested across the full spectrum of athletes (both elite and non-elite, male and female), in order to better understand athlete criminality.

\section{References}

Adams, A., and S. Carr. 2019. "Football Friends: Adolescent Boys' Friendships inside an English Professional Football (Soccer) Academy." Soccer and Society 20 (3): 471493.

Alea, N., and S. Bluck. 2003. "Why are you telling us that? A Conceptual Model of the Social Function of Autobiographical Memory." Memory 11: 165-178.

Allen, M., I. Greenlees, and M. Jones. 2011. "An Investigation of the Five-Factor Model of Personality and Coping Behaviour in Sport." Journal of Sport Sciences 29 (8): 841-850.

Anderson, L., and M. Brown. 2010. "Expanding Horizons of Risk in Criminology." Sociology Compass 4 (8): 544-554.

Atkinson, M., and K. Young. 2008. Deviance and Social Control in Sport. Leeds: Human Kinetics.

Aven, T. 2013. "On the Meaning and Use of the Risk Appetite Concept." Risk Analysis 33 (3): 462-468.

Bengtsson, T. T. 2013. “'It's What You Have to do!': Exploring the Role of High-Risk Edgework and Advanced Marginality in a Young Man's Motivation for Crime." Criminology and Criminal Justice: An International Journal 13 (1): 99-115.

Bertollo, M., C. Robazza, W. N. Falasca, M. Stocchi, C. Babiloni, C. Del Percio, N. Marzano, M. Iacoboni, F. Infarinato, F. Vecchio, C. Limatola, and S. Comani. 2012. "Temporal Pattern of Pre-Shooting Psycho-Physiological States in Elite Athletes: A Probabilistic Approach." Psychology of Sport \& Exercise 13 (2): 91-98.

Blackshaw, T., and T. Crabbe. 2004. New perspectives on Sport and Deviance: Consumption, Performativity and Social Control. London: Routledge.

Bryman, A. 2004. Social Research Methods. 2nd ed. Oxford: Oxford University Press.

Bunn, M. 2017. "Defining the Edge: Choice, Mastery and Necessity in Edgework Practice." Sport in Society 20 (9): 1310-1323.

Carless, D., and K. Douglas. 2017. "Narrative Research." The Journal of Positive Psychology 12 (3): 307-308. 
Caron, S.L., W. A. Halteman, and C. Stacy. 1997. "Athletes and Rape: Is There a Connection?” Perceptual and Motor Skills 85: 1379-1393.

Carr, S. 2012. Attachment in Sport, Exercise and Wellness. Abingdon: Routledge.

Carter, E. M., and M. V. Carter. 2007. “A Social Psychological Analysis of Anomie among National Football League Players." International Review for the Sociology of Sport 42 (3): 243-270.

Caruso, R. 2011. "Crime and Sport Participation: Evidence from Italian Regions over the Period 1997-2003.” The Journal of Socio-economics 40: 455-463.

Chase, S.E. 2005. "Narrative Inquiry: Multiple Lenses, Approaches, Voices." In The Sage Handbook of Qualitative Research, edited by N. K. Denzin, and Y.S. Lincoln, 651-679. Thousand Oak CA: Sage Publications Limited.

Chi, M. T. H. 2006. "Two Approaches to the Study of Experts' Characteristics." In The Cambridge Handbook of Expertise and Expert Performance, edited by K.A. Ericsson, N. Charness, P.J. Feltovich, and R. R. Hoffman, 21-30. New York, NY: Cambridge University Press.

Coakley, J. 2001. Sport in Society: Issues and Controversies. 7th ed. Boston: McGrawHill.

Coakley, J., and P. Donnelly. 2005. Sport in Society: Issues and Controversies. Toronto: McGraw-Hill.

Connor, J. 2009. "The Athlete as a Widget: How Exploitation Explains Elite Sport." Sport in Society 12 (10): 1369-1377.

Corkery, J. 2011. "Dangerous Sports and Obvious Risks - Anyone for Cricket?" Analysis sport and law journal 21 (3): 27-33.

Crabbe, T. 2000. "A Sporting Chance?: Using Sport to Tackle Drug Use and Crime." Drugs: Education, Prevention and Policy 7 (4): 381-391.

Creighton, G.M., J.L. Oliffe, E. McMillan, and E. M. Saewye. 2015. "Living for the Moment: Men Situating Risk-taking after the Death of a Friend." Sociology of Health and Illness 37 (3): 355-369.

Critcher, C. 2000. "Sport is damaging to your Health.” Recreation: 17-20.

Davis, B. S., and S. Menard. 2013. "Long Term Impact of Youth Sports Participation on Illegal Behaviour." The Social Science Journal 50: 34-44.

Desmond, M. 2004. "Methodological Challenges Posed in Studying an Elite in the Field." Area 36 (3): 262-269.

de Vries, B. 2018. "The Unsung Bonds of Friendship — and Caring-Among Older Adults." Generations 42 (3): 77-81. 
Dhami, M. K., and D. R. Mandel. 2012. "Crime as Risk Taking.” Psychology, Crime and Law 18 (3): 389-403.

Driessens, O. 2013. "Celebrity Capital: Redefining Celebrity using Field Theory." Theory and Society 42: 543-560.

Duke, K. 2002. "Getting Beyond the 'Official Line': Reflections on Dilemmas of Access, Knowledge and Power in Researching Policy Networks." Journal of Social Policy 31 (1): 39-60.

Dunning, E., and I. Waddington. 2003. "Sport as a Drug and Drugs in Sport." International Review for the Sociology of Sport 38 (3): 351-368.

Ermer, E., L. Cosmides, and J. Tooby. 2008. "Relative Status Regulates Risky Decision Making about Resources in Men: Evidence for the Co-Evolution of Motivation and Cognition." Evolution and Human Behaviour 29: 106-118.

Ferrell, J. 1999. "Cultural Criminology.” Annual Review of Sociology 25: 395-418.

Fisher, L. A., and A. D. Anders. 2019. "Engaging With Cultural Sport Psychology to Explore Systemic Sexual Exploitation in USA Gymnastics: A Call to Commitments." Journal of Applied Sport Psychology: 1-17.

Fletcher, R. 2008. "Living on the Edge: The Appeal of Risk Sports for the Professional Middle Class." Sociology of Sport Journal 25 (3): 310-330.

Forbes, G. B., A. H. Pakalka, K. B. White, and L. E. Adams-Curtis. 2006. "Dating Aggression, Sexual Coercion, and Aggression-Supporting Attitudes among College Men as a Function of Participation in Aggressive High School Sports." Violence against Women 12 (5): 441-455.

Forsey, C. 2012. Men on the Edge: Taking Risks and Doing Gender among Base Jumpers. Winnipeg: Fernwood Publishing.

Frey, J. H. 1994. "Deviance of Organizational Subunits: The Case of College Athletic Departments.” Journal of Sport \& Social Issues, 18 (2): 110-122.

Giulianotti, R. 2015. Routledge Handbook of the Sociology of Sport. London: Routledge.

Gladwell, M. 2009. Outliers: The Story of Success. London: Penguin Books.

Grant, M. A., and P.G. Schempp. 2013. "Analysis and Description of Olympic Gold Medalists' Competition-Day Routines." Sport Psychologist 27 (2): 156-170.

Green, C. 2009. Every Boy's Dream: England's Football Future on the Line. London: A\&C Black.

Groombridge, N. 2016. Sports Criminology: A Critical Criminology of Sport and Games. Bristol: Policy Press. 
Gruneau, R.S. 1980. "Freedom and Constraint: The Paradoxes of Play, Games, and Sports.” Journal of Sport History 7 (3): 68-86.

Halsey, M. 2008. "Narrating the Chase: Edgework and Young People's Experiences of Crime." In The Critical Criminology Companion, edited by T. Anthony, and C. Cunneen, 105-117. Sydney: Hawkins Press.

Hartmann, D., and M. Massoglia. 2007. "Reassessing the Relationship between High School Sports Participation and Deviance: Evidence of Enduring, Bifurcated Effects." The sociological Quarterly 48 (3): 485-505.

Haynie, D. L., N. J. Doogan, and B. Soller. 2014. "Gender, Friendship Networks, and Delinquency: A Dynamic Network Approach.” Criminology 52 (4): 688-722.

Helfgott, J. B. 2008. Criminal Behaviour: Theories, Typologies and Criminal Justice. LA: Sage.

Hochstetler, A., and H. Copes. 2016. "Qualitative Criminology's Contributions to Theory.” In The Handbook of Criminology, edited by A.R. Piquero, 497-520. Chichester: Wiley Blackwell.

Holloway, I. 2008. A-Z of Qualitative Research in Health Care. 2nd ed. Chichester: Blackwell Publishing.

Holloway, I., and D. Freshwater. 2007. "Vulnerable story telling: narrative research in nursing." Journal of Research in Nursing 12 (6): 703-711.

Holloway, I., and S. Wheeler. 2010. Qualitative Research in Nursing and Healthcare. 3rd ed. Chichester: Wiley-Blackwell.

Horvath, P., and M. Zuckerman. 1993. "Sensation Seeking, Risk Appraisal, and Risky Behaviour." Personality and Individual Differences 14 (1): 41-52.

House, T. 1989. The Jock's Itch: The Fast-Track World of the Professional Ballplayer. Chicago: Contemporary books.

Hunton, P. 2012. "Data Attack of the Cybercriminal: Investigating the Digital Currency of Cybercrime." Computer Law and Security Review 28: 201-207.

Jackson, A., K. Gilliland, and L. Veneziano. 2006. "Routine Activity Theory and Sexual Deviance among Male College Students." Journal of Family Violence 21 (7): 449-460.

Jamieson, L. M., and T. J. Orr. 2009. Sport and Violence: A Critical Examination of Sport. London: Butterworth-Heinemann.

Jones, K. 2003. "The Turn to a Narrative Knowing of Persons: One Method Explored." Journal of Research in Nursing 8 (1): 60-71. 
Jones, I., L. Brown, and I. Holloway. 2013. Qualitative Research in Sport and Physical Activity. London: Sage.

Katz, J. 1988. Seductions of Crime: Moral and Sensual Attractions in Doing Evil. New York: Basic Books.

Kellett, S., and H. Gross. 2006. "Addicted to Joyriding? An Exploration of Young Offenders' Accounts of their Car Crime." Psychology, Crime and Law 12 (1): 39-59.

Kiyani, R., A. Mohammadi, L. Sattarzadeh. 2011. "The Survey Compares Mental Health and Happiness of Athlete and Non-Athlete Employed People." Procedia - Social and Behavioural Sciences 30: 1894-1896.

Krause, P., J. Heindle, A. Jung, B. Langguth, G. Hajak, and P.G. Sand. 2014. "Risk Attitudes and Birth Order." Journal of Health Psychology 19 (7): 858-868.

Kudlac, C. S. 2010. Fair or Foul: Sports and Criminal Behaviour in the United States. Santa Barbara, California: Praeger/ABC-CLIO.

Lancaster, K. 2017. "Confidentiality, Anonymity and Power Relations in Elite Interviewing: Conducting Qualitative Policy Research in a Politicised Domain." International Journal of Social Research Methodology 20 (1): 93-103.

Langseth, T. 2011. "Risk Sports-Social Constraints and Cultural Imperatives." Sport in Society 14 (5): 629-644.

Laurendeau, J. 2008. "Gendered Risk Regimes: A Theoretical Consideration of Edgework and Gender." Sociology of Sport Journal 25 (3): 293-309.

Leonard, D. 2006. "A World of Criminals or a Media Construction? Race, Gender, Celebrity, and the Athlete/Criminal Discourse." In Handbook of Sports and Media, edited by A.A. Raney, and J. Bryant, 523-542. Mahwah: Lawrence Erlbaum Associates.

Lois, J. 2003. Heroic Efforts: The Emotional Culture of Search and Rescue Volunteers. New York: New York University Press.

Lyng, S. 1990. "Edgework: A Social Psychological Analysis of Voluntary Risk Taking." American Journal of Sociology 95 (4): 851-886.

Lyng, S. 1993. "Dysfunctional Risk Taking: Criminal Behaviour as Edgework." In Adolescent Risk Taking, edited by N. Bell, and R. Bell, 107-130. London: Sage Publications.

Lyng, S. 2004. "Crime, Edgework and Corporeal Transaction.” Theoretical Criminology 8 (3): 359-375.

Lyng, S. 2005. "Edgework and Risk Taking Experience.” In Edgework: The Sociology of Risk-Taking, edited by S. Lyng, 3-16. New York: Routledge. 
Maher, M.A., C. J. Thomson, and S. R. Carlson. 2015. "Risk-Taking and Impulsive Personality Traits in Proficient Downhill Sports Enthusiasts." Personality and Individual Differences 79: 20-24.

Maupin, A. 2017. Logical Family: A Memoir. New York: Harper Collins.

McCray, K. L. 2015. "Intercollegiate Athletes and Sexual Violence: A Review of Literature and Recommendations for Future Study." Trauma, Violence and Abuse 16 (4): 438-443.

McGovern, R., and W. McGovern. 2011. "Voluntary Risk-Taking and Heavy-End Crack Cocaine Use: An Edgework Perspective." Health, Risk and Society 13 (5): 487500 .

Messner, M. 1990. "Boyhood, organised sports and the construction of masculinities.” Journal of Contemporary Ethnography 18: 416-444.

Messner, M. A. and D. F. Sabo. 1990. Sport, Men, and the Gender Order: Critical Feminist Perspectives. Champaign, Ill: Human Kinetics.

Messner, M. A., and M. A. Stevens. 2002. "Scoring Without Consent: Confronting Male Athletes' Violence against Women." In Paradoxes of Youth and Sport, edited by M. Gatz, 225-239. Albany, N.Y: State University of New York Press.

Mikecz, R. 2012. "Interviewing Elites: Addressing Methodological Issues.” Qualitative Inquiry 18 (6): 482-493.

Miller, R. 2000. Researching Life Stories and Family Histories. London: Sage Publications.

Miller, W. J. 2005. "Adolescents on the Edge: The Sensual Side of Delinquency." In Edgework: The Sociology of Risk-Taking, edited by S. Lyng, 153-171. New York: Routledge.

Morris, Z. S. 2009. “The Truth about Interviewing Elites.” Politics 29 (3): 209-217.

Moston, S., T. Engelberg, and J. Skinner. 2015. “Athletes' and Coaches' Perceptions of Deterrents to Performance-Enhancing Drug Use." International Journal of Sport Policy and Politics 7 (4): 623-636.

Munro Hendry, P. 2007. “The Future of Narrative.” Qualitative Inquiry 13 (4): 487-498.

Murphy, P., and I. Waddington. 2007. “Are Elite Athletes Exploited?" Sport in Society 10 (2): 239-255.

Newmahr, S. 2011. "Chaos, Order and Collaboration: Toward a Feminist Conceptualization of Edgework." Journal of Contemporary Ethnography 40 (6): 682712. 
Nichols, G. 2007. Sport and Crime Reduction: The Role of Sports in Tackling Youth Crime. London; New York: Routledge.

O’Connor, P. 2015. "Telling Moments: Narrative Hot Spots in Accounts of Criminal Acts." In Narrative Criminology: Understanding Stories of Crime, edited by L. Presser, and S. Sandberg, 174- 203. New York: New York University Press.

Ortiz, S. M. 2004. "Leaving the Private World of Wives of Professional Athletes: A Male Sociologist's Reflections." Journal of Contemporary Ethnography 33 (4): 466478.

Pappas, N. T., P. C. McKenry, and B. S. Catlett. 2004. "Athlete Aggression on the Rink and Off the Ice." Men \& Masculinities 6 (3): 291-312.

Parlebas, P. 2002. "Elementary Mathematical Modelization of Games and Sports." In The Explanatory Power of Models, edited by R. Franck, 197-227. Boston, MA: Kluwer.

Patrick, H., A. M. Ryan, C. Alfeld-Liro, J. A. Fredricks, L.Z. Hruda, and J. S. Eccles. 1999. "Adolescents' Commitment to Developing Talent: The Role of Peers in Continuing Motivation for Sports and the Arts." Journal of Youth and Adolescence 28 (6): 741-763.

Penrod, J., D. B. Preston, R. Cain, and M. T. Starks. 2003. "A Discussion of Chain Referral as a Method of Sampling Hard-to-Reach Populations." Journal of Transcultural Nursing 14 (2): 100-107.

Polkinghorne, D.E. 2007. "Validity Issues in Narrative Research." Qualitative Inquiry 13 (4): 471-486.

Presser, L. 2009. "The Narratives of Offenders.” Theoretical Criminology 13 (2): 177200.

Presser, L., and S. Sandberg. 2015. "What is the Story?" In Narrative Criminology: Understanding Stories of Crime, edited by L. Presser, and S. Sandberg, 1-20. New York: New York University Press.

Pummell, B., C. Harwood, and D. Lavallee, D. 2008. "Jumping to the Next Level: A Qualitative Examination of Within-Career Transition in Adolescent Event Riders." Psychology of Sport and Exercise 9 (4): 427-447.

Rajah, V. 2007. "Resistance as Edgework in Violent Intimate Relationships of DrugInvolved Women." British Journal of Criminology 2: 196-213.

Reardon, C.L. and R. M. Factor. 2010. "A Systematic Review of Diagnosis and Medical Treatment of Mental Illness in Athletes." Sports Medicine 40 (11): 961980 .

Rice, G. 2010. "Reflections on Interviewing Elites.” Area 42 (1):70-75. 
Roderick, M., I. Waddington, and G. Parker. 2000. "Playing Hurt: Managing Injuries in English Professional Football." International Review for the Sociology of Sport 35 (2): 165-180.

Roth, S. 2015. "Aid Work as Edgework - Voluntary Risk-Taking and Security in Humanitarian Assistance, Development and Human Rights Work." Journal of Risk Research 18 (2): 139-155.

Russell, J.S. 2005. "The Value of Dangerous Sport." Journal of the Philosophy of Sport 32 (1): 1-19.

Sandberg, S. 2009. "Gangster, Victim or Both? The Interdiscursive Construction of Sameness and Difference in Self-Presentations." British Journal of Sociology 60 (3): 523-542.

Sawyer, R. G., E. E. Thompson, and A. M. Chicorelli. 2002. "Rape Myth Acceptance among Intercollegiate Student Athletes: A Preliminary Examination." American Journal of Health Studies 18 (1): 19-25.

Shenton, A. K., and S. Hayter. 2004. "Strategies for Gaining Access to Organisations and Informants in Qualitative Studies." Education for Information 22 (3): 223-231.

Smith, B. 2010. "Narrative Inquiry: On-going Conversations and Questions for Sport and Exercise Psychology Research." International Review of Sport and Exercise Psychology 3 (1): 87-107.

Smith, B., and A. Sparkes. 2009. "Narrative Inquiry in Sport and Exercise Psychology: What it can mean, and why we might do it?" Psychology of Sport and Exercise 10: 111 .

Smith, C. 2005. "Financial Edgework: Trading in Market Currents." In Edgework: The Sociology of Risk-Taking, edited by S. Lyng, 187-20. New York: Routledge.

Steinberg, L., and K. C. Monahan. 2007. "Age Differences in Resistance to Peer Influence.” Developmental Psychology 43 (6): 1531-1543.

Steiner, H., K. Denny, and P. Stemmle. 2010. "Adaptive Styles in Elite Collegiate Athletes: The Role of Activation and Self-Regulation." Personality and Mental Health 4 (3): 163-171.

Sulloway, F. J., and R. L. Zweigenhaft. 2010. "Birth Order and Risk Taking in Athletics: A Meta-Analysis and Study of Major League Baseball." Personality and Social Psychology Review 14 (4): 402-416.

Swann, C., A. Moran, and D. Piggott. 2015. "Defining Elite Athletes: Issues in the Study of Expert Performance in Sport Psychology." Psychology of Sport and Exercise $16(1): 3-14$.

Teitelbaum, S. H. 2005. Sports Heroes, Fallen Idols. Lincoln: University of Nebraska Press. 
Terry, P. C., and J.J. Jackson. 1985. "The Determinants and Control of Violence in Sport." Quest. 37 (1): 27-37.

Utting, D, 1996. Reducing Criminality among Young People: A Sample of Relevant Programmes in the United Kingdom. London: Home Office Research and Statistics Directorate.

Vaux, A. 1988. Social Support: Theory, Research and Intervention. New York: Praeger.

Way, N. 2013. "Boys' Friendships during Adolescence: Intimacy, Desire, and Loss." Journal of Research on Adolescence. 23 (2): 201-13.

Weiss, M. R., A. L. Smith, and M. Theeboom. 1996. ““"That's what Friends are for": Children's and Teenagers' Perceptions of Peer Relationships in the Sports Domain." Journal of Sport and exercise Psychology 18: 347-379.

Welch, C., R. Marschan-Piekkari, H. Penttinen, and M. Tahvanainen. 2002. "Corporate Elites as Informants in Qualitative International Business Research.” International Business Review 11 (5): 611-628.

Woike, B. 2008. "The State of the Story in Personality Psychology." Social and Personality Psychology Compass 2: 434-443.

Woods, R. 2007. Social Issues in Sport. Champaign, IL: Human kinetics.

Yar, M. 2014. Crime, Deviance and Doping: Fallen Sports Stars, Autobiography and the Management of Stigma. Basingstoke: Palgrave Macmillan.

Young, K. 2000. “Sport and Violence.” In Handbook of Sport Studies, edited by J. Coakley, and E. Dunning, 23-59. London: Sage.

Zuckerman, M. 1979. Sensation Seeking: Beyond the Optimal Level of Arousal. Hillsdale: Earlbaum.

Zuckerman, M. 2007. Sensation Seeking and Risky Behaviour. Washington, DC: American Psychological Association. 


\begin{tabular}{|c|c|c|c|c|c|}
\hline $\begin{array}{c}\text { Name } \\
\text { (pseudonym) }\end{array}$ & Gender & $\begin{array}{c}\text { Current } \\
\text { age }\end{array}$ & Sport & $\begin{array}{l}\text { Age at } \\
\text { time of } \\
\text { offence }\end{array}$ & Nature of offence(s) \\
\hline Archie & Male & 45 & Football & 21,27 & $\begin{array}{l}\text { Offences against the person } \\
\text { - assault. } \\
\text { Drug offences - } \\
\text { possession. }\end{array}$ \\
\hline Billy & Male & 24 & Boxing & 22 & $\begin{array}{l}\text { Offences against the person } \\
\text { - assault. } \\
\text { Offences against property - } \\
\text { criminal damage. }\end{array}$ \\
\hline Charlie & Male & 44 & Football & 18 & $\begin{array}{l}\text { Major driving offences - } \\
\text { dangerous driving; driving } \\
\text { without insurance. }\end{array}$ \\
\hline Dougie & Male & 40 & Boxing & 18 & $\begin{array}{l}\text { Offences against property - } \\
\text { criminal damage } \\
\text { (vandalism); theft. }\end{array}$ \\
\hline Ethan & Male & 25 & $\begin{array}{l}\text { Rugby } \\
\text { Union }\end{array}$ & 20 & $\begin{array}{l}\text { Offences against the person } \\
\text { - Grevious Bodily Harm. }\end{array}$ \\
\hline Finn & Male & 38 & Football & $\begin{array}{l}21,23,24, \\
28\end{array}$ & $\begin{array}{l}\text { Drug offences - supply of } \\
\text { drugs; possession of drugs } \\
\text { with intent to supply; } \\
\text { importation. }\end{array}$ \\
\hline George & Male & 34 & Football & $18,19,20$ & $\begin{array}{l}\text { Offences against property - } \\
\text { theft }\end{array}$ \\
\hline
\end{tabular}




\begin{tabular}{|c|c|c|c|c|c|}
\hline Harry & Male & 45 & $\begin{array}{l}\text { Rugby } \\
\text { union }\end{array}$ & 26,38 & $\begin{array}{l}\text { Offences against the person } \\
\text { - assault } \\
\text { Major driving offences - } \\
\text { driving while under the } \\
\text { influence of alcohol }\end{array}$ \\
\hline Isaac & Male & 29 & $\begin{array}{l}\text { Pro } \\
\text { skating }\end{array}$ & 19 & $\begin{array}{l}\text { Offences against property - } \\
\text { criminal damage. } \\
\text { Drug offences -possession } \\
\text { of drugs. }\end{array}$ \\
\hline Joshua & Male & 48 & $\begin{array}{l}\text { Non- } \\
\text { contact } \\
\text { team sport }\end{array}$ & 40 & $\begin{array}{l}\text { Drug offences - supply of } \\
\text { drugs; possession of drugs } \\
\text { with intent to supply; } \\
\text { importation. }\end{array}$ \\
\hline
\end{tabular}

Table 1. Overview of Sample 


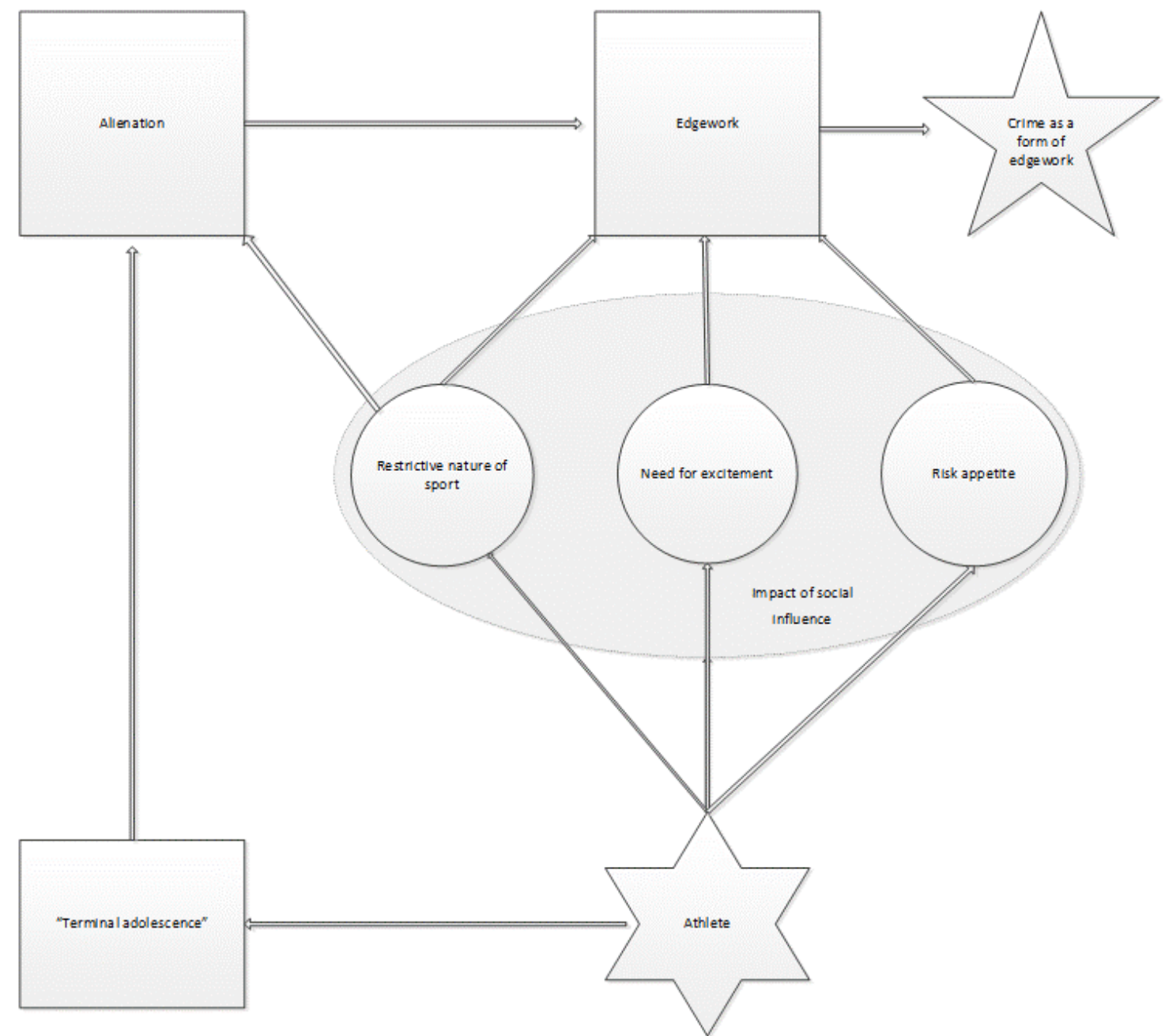

Figure 1: A Framework for Understanding Athlete Criminality 